\title{
URINARY WHITE CELL EXCRETION AFTER CHEST PAIN
}

\author{
Captain ROBERT C. MENZIES, M.B., Ch.B., R.A.M.C. \\ Law Hospital, Carluke, Lanarkshire *
}

SUMMARY: On a series of 28 male patients, it was shown that a count of six or more urinary white cells, using the method of McGeachie and Kennedy (1963), was strongly indicative of myocardial infarction if preceeded by chest pain. Controls who had chest pain but no infarction did not show rates of white cell excretion as high as this, but counts of less than six cells were of much less diagnostic significance.

The findings are discussed, and the methods criticised. A hypothesis to account for the findings and suggestions as to future work on this subject is put forward.

\section{Introduction}

In instituting this investigation, the object was to discover what connection, if any, existed between urinary 'white cell' excretion and chest pain of cardiac origin in the presence of true infarction or without true infarction.

Addis (1926) demonstrated the rate of excretion of urinary 'white cells' to be in the region of 322,500 cells per twelve hours. In the term 'white cells' he included leucocytes and non-squamous epithelial cells from the renal tract. Up to 1964, estimates of white cell excretion were largely inclusive of these two sources on account of the difficulty of staining the cells differentially, when Prescott and Brodie (1964) produced a relatively simple stain for differentiating cell types in the urine. This is based on the familiar peroxide reaction. The principal reagent used is diaminofluorene which stains true polymorph leucocytes deep blue.

Since the work of Addis, and on account of the importance of urinary tract infection, and its early diagnosis and treatment, and the obvious possible relationship between cellular excretion and such infection there have been many attempts (Goldring, 1931, Houghton and Pears, 1937, Hutt, Chalmers, MacDonald and de Wardener, 1961 and Kennedy, Ormonde and Murdoch, 1964) to establish firmly the normal, or more important, the upper limit of normal, for the excretion of white cells in the urine. The actual values found in such series vary widely (from 18,000 cells per hour to 400,000 cells per hour) but for 1964 , the concensus of opinion was that more than 400,000 cells per hour was an abnormal rate of excretion. In the course of these investigations, other factors were discovered which were related to the number of cells excreted and, in the light of such an apparent multi-factorial aetiology, the writer was prompted to undertake this study.

\section{Materials and method}

The series consisted basically of 39 patients, male and female, who were admitted with a presumptive diagnosis of myocardial infaretion to a general medical unit in a large provincial hospital near Glasgow. The diagnosis of myocardial infarction was made or refuted on the basis of clinical history and examination, electrocardiography and haematological and biochemical laboratory studies. It was then reviewed at discharge routinely, and again some months later for the purpose of this study.

\footnotetext{
* Now Medical Reception Station, School of Infantry, Warminster.
} 
As the object of the exercise was to estimate the rate of urinary 'white cell ' excretion (i.e. leucocytes and epithelial cells) daily over the first two weeks of hospitalisation, patients who developed oliguria or who gave a past or present history of urinary tract disease were specifically excluded. Also, any patient who died during the first fourteen days following admission was excluded from the final figures; these are consequently not indicative of the mortality for this period.

Owing to some limitations of time, equipment and assistance it was decided that estimations would be made on mixed random specimens of urine, specifically excluding the first specimen of the day. As fluid charts were maintained, it was possible to exclude cases of oliguria. To this urine was applied the technique described by McGeachie and Kennedy (1963). No staining technique was used. Any patient who, on any day of the fourteen-day period under consideration, showed a cell count of more than five white cells had a midstream specimen of urine sent for bacteriological study in order to exclude infection. The number of cells was plotted on a graph daily for each patient. Since, in this series, the patients who had proved infarction and those who did not have infarction were treated in exactly the same way for the period in question, the latter group served as controls in the subsequent calculations.

\section{Results}

It was found in practice that the type of graph obtained in respect of the male patients tended to fall into one of two patterns-those which showed levels of six cells or more on one or more days, and then fell below this level and stayed below it, and those which never went above this number. This was not true of the counts done on the urine of the eleven women in the series; the shape of the graphs obtained in their case was so bizarre as to be unintelligible, and they were excluded from the investigation. It is assumed that this was due to a defect in the technique of collecting their urine.

The findings of the remaining 28 male patients are summarised in Table I. On account of the small numbers involved, Fisher's Exact Test for a $2 \times 2$ table was applied, and this showed $\mathrm{P}<0.0002$.

Table I

Analysis of urinary cell counts ( 28 male patients)

\begin{tabular}{l|c|c|c}
\multicolumn{1}{c|}{ Cells } & Infarct proved & No infarct & Totals \\
\hline Less than 6 & 5 & 10 & 15 \\
6 or more than 6 & 13 & 0 & 13 \\
\hline Totals & 18 & 10 & 28 \\
\hline
\end{tabular}

Present symptoms, past history, clinical signs and laboratory findings were recorded for each patient. It was found to be impossible to correlate any particular symptom, past event, sign or finding with a raised urinary white cell count in a statistically meaningful way. Since e.c.g's and serum enzymes were used in the diagnosis of infarct, these were not included in this study.

As many of these patients were treated over the period in question with anticoagulants or diuretics, singly or in combination, the possibility of a connection with these drugs was investigated; no statistical connection was found. 
Only one patient died subsequent to having been in the series and came to autopsy. The immediate cause of death was pulmonary embolus from a deep vein thrombosis. The infarct diagnosed in the ward was confirmed macroscopically and histologically, and histology of the kidneys showed only changes compatible with the patient's age ( 77 years) and some degree of congestion which was most probably agonal.

\section{Discussion}

As noted above, the cellular excretion rate has been reported by a number of workers to be related to a variety of circumstances. Goldring (1931) showed that a temperature over $100^{\circ} \mathrm{F}$ (in association with pneumonia) would raise the rate of cellular loss. Exercise was also shown to do this by Roberts (1935); Elden and Cooney (1935) showed that the last trimester of pregnancy had a similar effect in otherwise normal women. Houghton and Pears (1957) showed that there was no statistically significant difference in the rate of cellular excretion between the sexes.

In the course of investigating cases of acute and chronic pyelonephritis, Hutt, Chalmers, MacDonald and de Wardener (1961) showed that administration of pyrogen to patients with these diseases increased the cellular excretion rate to abnormal levels and, three years later, Kennedy, Ormonde and Murdoch (1964) showed that prednisolone will do the same in cases of chronic pyelonephritis; the diagnostic usefulness of this is well known.

By using the stain already mentioned, Prescott (1965) showed that excretion of renal tubular cells was elevated by administration of phenacetin $(3.6 \mathrm{~g} /$ day $)$, caffeine $(2.4 \mathrm{~g} /$ day $)$ and aspirin ( $3.6 \mathrm{~g} /$ day), whilst administration of paracetamol or a placebo produced no such increase. This was, incidentally, the first time nephhrotoxicity had been shown in association with phenacetin and caffeine. Lindsay, Lunan, McGeachie and Linton (1967) demonstrated a significant increase in the excretion of urinary white cells following surgery (other than to the urinary tract) in females, but not in males.

The results of the investigation here described tend to suggest that, in male patients, the finding of a white cell count of six or more was highly indicative of an infarct, whilst a count of less than six cells was of a very dubious meaning, although, perhaps, it tended to suggest no actual infarction. It was found impossible to relate this finding to any other clinical or therapeutic observation. Female patients were excluded from the series for reasons already stated.

Criticism of the methods employed is easily made; twenty-four hour collections would have enabled comparison with figures obtained in other work and would generally have helped in accuracy; the staining method referred to would have enabled the nature of the cells counted to have been established; concurrent blood white cell counts would have been interesting in establishing the possible existence of a " renal threshold" for leucocytes although a few random white blood cell counts, admittedly not statistically significant, on certain patients suggest that this does not exist; and, lastly, better technique in the collection of urine from the female subjects would have enabled comparison in this group as well. With regard to the last point, the collection of 'clean' specimens of urine from women, involving much handling by nurses, is not an aesthetic procedure and is not well tolerated regularly by women who are already considerably upset by serious disease. 
This series was purely one of observation and very little attempt to discover reasons for the findings was made. There was no statistical correlation between these findings and any one clinical factor except possibly pyrexia. One interesting possibility is that this is a manifestation of renal intoxication by products from the necrosed muscle of the infarct as happens, for example, in the 'crush syndrome'. In this respect it would be instructive to repeat the series, with the modifications already mentioned, together with a series of estimations on such products of heart muscle necrosis as creatine phosphokinase, butyrate dehydrogenase, lactic dehydrogenase (iso-enzyme 1) and glutamic oxalacetic transaminase. This sort of experiment could easily be added to a series of induced infarcts in dogs as described by Rees and Redding (1968).

\section{Acknowledgements}

To Dr. J. Buchanan, Consultant Physician, Law Hospital, Carluke, Lanarkshire, for permission to publish this work involving his patients. Dr. J. B. de V. Weir, Physiology Department, Glasgow University, for advice and aid with the statistics, Sisters and Staff of Wards 19 and 20, Law Hospital, Carluke, for assistance in the collection of urine, and to my wife for practical assistance.

\section{REFERENCES}

ADDIS, T. (1926). J. clin. Invest. 2, 409.

EldEN, C. A. and COONEY, J. W. (1935). J. clin. Invest, 14, 889.

Goldring, W. (1931). J. clin. Invest. 10, 355.

Houghton, B. J. and Pears, M. A. (1957). Brit. med. J. i, 622.

Hutt, M. S. R., Chalmers, J. A., MacDonald, J. S. and de Wardener, H. E. (1961). Lancet i, 351.

Kennedy, W. P. U., Ormonde, N. W. H. and Murdoch, J. MCG. (1964). Brit. J. Urol. $36,354$.

Lindsay, R. M., Lunan, B., MCGeachie, J. and Linton, A. L. (1967). Brit. med. J. iii, 83.

McGeachie, J. and KenNedy, A. C. (1963). J. clin. Path. 16, 32.

Prescott, L. F. and Brodie, D. E. (1964). Lancet ii, 940.

PrescotT, L. F. (1965). Lancet ii, 91.

ReEs, J. R. and ReDding, V. J. (1968). Cardiovasc. Res. 2, 43.

Roberts, A. M. (1935). J. clin. Invest. 14, 31.

\section{Preliminary Announcement-Corps Occasions for 1970}

\section{Provisional dates are as follows:-}

General and Officers Funds, R.A.M.C. Association, and Corps Mess Fund 29 May

Army Medical Services Swimming Gala

12 June

R.A.M.C. Officers' Dinner (7.30 for 8 p.m.)

2 July

R.A.M.C. Officers' 'At Home ' (4-6 p.m.)

3 July

Corps Sports

4 July

R.A.M.C. Training Centre and Old Comrades Church Parade and

'At Home'

5 July

Corps Golfing Society-Spring Meeting, Worplesden

17 April

Summer Meeting, North Hants

6 July

Autumn Meeting, New Zealand

6 October

R.A.M.C. Non-Medical Officers' Dinner Club

9 October 